Dhaka Univ. J. Biol. Sci. 26(2): 175-187, 2017 (July)

\title{
GRASSLAND SPECIALIST BIRDS IN A MANAGED HABITAT OF NORTH-EAST BANGLADESH
}

\author{
Muntasir AKash $^{*}$, Tania Khan ${ }^{1}$ and Sayam U. ChOWdhury ${ }^{2}$ \\ Department of Zoology, University of Dhaka, Dhaka-1000, Bangladesh
}

Key words: Grassland birds, Toxic grasses, Community ecology, Bird migration

\begin{abstract}
A seven-month spanned study from November, 2015 to May, 2016 was carried out to investigate the status and fluctuation of grassland dependent birds in a Saccharum-Imperata patch locating in the northeastern Bangladesh under ownership of a tea-garden; applying line transects with direct observation and diversity index. A total of 2586 individuals of 110 species was observed, grassland specialists constituted 829 (32\%) individuals from 39 (35\%) species. Only seven non-passerine specialists were observed against 32 passerine specialists whereas 19 being resident and 20 wintering species. Of the grassland specialists, $31 \%$ turned out as few, 33\% fairly common, $21 \%$ common and $15 \%$ very common. Insectivores and seed-eaters were dominant feeding guilds over scavengers and omnivores at the site yielding nine categories. Specialists scored the highest value in Shannon's Index for November $\left(\mathrm{H}_{\text {sp.nov }}^{\prime}=2.81\right)$ followed by a steady decline throughout the study period. The largest winter congregation of Yellow-breasted Bunting and Common Rosefinch in Bangladesh was observed and sighting of Black-headed Bunting was the fourth national record. The site was found to be supporting breeding population of Golden-headed Cisticola so far only known to country's inventory. Despite once supporting about 10 extirpated avian species and still being diverse, adequate information on grasslands is still wanting in Bangladesh.
\end{abstract}

\section{Introduction}

Evolved in parallel with periodic and frequent disturbances, grassland - together with the dominating monocotyledonous Poaceae plants and the coevolved specialist fauna - stands as a complex, distinctive, diverse and globally spread biome ${ }^{(1-2)}$. Grasslands contribute nearly a quarter of the world's vegetation cover from the tropics to the temperate regions, attributed by both natural and anthropogenic tree-growth inhibiting factors and broad range of rainfall intensity, comprising an area of about 52.5 million $\mathrm{sq} \mathrm{km}^{(2)}$.

\footnotetext{
*Author for correspondence: <akashmuntasir10@gmail.com>. 'Bangladesh Bird Club, House-11, Road-4, Banani D.O.H.S., Kakali, Dhaka-1206, Bangladesh. ${ }^{2}$ Spoon-billed Sandpiper Task Force, Flat - 501, House - 16/C , Road - Tallabag, Sobhanbagh, Dhaka-1207, Bangladesh.
} 
Of the four major sub-continental grassland types, Phragmites-Saccharum-Imperata hygrophilous formation sways from the Panjab plains to the North-east India as well as through watersheds of the Ganges-Brahmaputra-Meghna delta in south ${ }^{(3)}$. This subtropical grass complex, due to their presence on river alluviums and floodplains and correlation with monsoon, is often referred as 'wet savanna'(3). Bangladesh, as the existing literature suggest and geographically, betokens this formation, furthermore, having 285 species of wild grass ${ }^{(4-5)}$.

Grasslands in Bangladesh encompass about 5 percent of total forested area and positioned atop in the worst affected habitats' list of the country(6). Along with the bygone habitats, Bangladesh has also lost many habitat specialist species i.e., dependent on and adapted to grasslands for completing full life cycle or part of it (can be breeding, nesting, feeding, migratory or wintering species)(7). Of country's 31 extirpated species, 10 of both mammalian and avian species were directly associated with grasslands including all three species of Asian Rhinoceroses, Blackbuck, Blue Bull, Swamp Deer, two species of Florican and Francolin, three species of Parrotbill, one Patridge, White-winged Duck and globally extinct Pink-headed Duck(6,8).

At present, except those of the southern coastal belt and of the northern tributaries of the Jamuna River, grasslands from central regions are completely gone and habitats that reminisce the characteristic north-east Indian grass complex are extremely scattered either disturbed by random grazing practices or pocketed by human settlements, in peril and treated as the least concerned wildlife habitat ${ }^{(6,9)}$. Despite being pocketed and heavily altered, these habitats still harbor many rare and elusive fauna along with a handful of threatened species like Yellow-breasted Bunting, Bristled Grassbird, Fishing Cat, Indian Hare and Bengal Fox etc. ${ }^{(6,10-11)}$.

Therefore, to check the declining trend of grassland habitats and dependent specialists, perceiving grassland birds' ecology and biology has become pertinent. However, other than the annotation from Khan (1988), any further literary study on indigenous grassland birds are still lacking in Bangladesh ${ }^{(12)}$.

In this study, objectives are to (1) investigate specialist birds in a grassland patch being under routinized management but similar to north-eastern 'wet-savanna' formation and (2) document their periodicity across the winter; thus to update the shortfall of information on grassland birds of Bangladesh and provide baseline for comparative studies with vegetation and management layouts.

\section{Material and Methods}

Comprising an area of 17.59 hectares, the site $\left(24^{\circ} 12^{\prime} 11^{\prime \prime} \mathrm{N}, 91^{\circ} 51^{\prime} 55^{\prime \prime} \mathrm{E}\right)$ falls under ownership and management of the Kurma Tea Estate located in the north-eastern administrative district of Moulvibazar of Sylhet division. The tea garden is $33 \mathrm{~km}$ away from Moulvibazar district and $10 \mathrm{~km}$ from the Adampur Reserve Forest northwardly 
whereas the Indian States of Tripura and Assam are respectively $3 \mathrm{~km}$ on the south and $35 \mathrm{~km}$ on the east. Likewise bordering Tripura and Assam, climate of the region is of tropical savanna climate being marked with considerable precipitation due to the southwest monsoon ${ }^{(13-14)}$.

Typical of the north-eastern part of Bangladesh, Ravenna grass Saccharum ravennae is the most dominant and the tallest species forming a typical elephant grass set up with dense congregation within the area(5). Cogon grass Imperata cylindrica forms the second sheet layer; as a majority where Ravenna grass is sparse or absent. A GIS-based habitat map was developed to characterize the survey site based on spread and dominance of the grass species (Fig. 1). We divided the study area into six micro-habitats, these include (1) bush-associated area with predominance of Clerodendrum infortunatum and Lantana sp. (BA), (2) dense tall grass formation with characteristic heavy growth of Ravenna grass (DT), (3) sparse grass along road with sparse Ravenna grass, Cogon grass and other lessdominating grasses (SG), (4) sparse short grass with spread of Cogon grass (SS), (5) grasses along the creek attributed with Ravenna grass, and sedges and their integral association within creek emergence (AC) and (6) crop-associated area with presence of lentils and only creeping grasses (CA). Nomenclature and identification were followed after Ahmed et al. (2008 a,b), Siddiqui et al. (2008a) $)^{(5,15-16)}$. The dimension of the area, distances, mapping, habitat data attributes were estimated with ArcGIS 10.3.1 and Google Earth Pro. Ground truthing was carried out by Global Positioning System (GPS) navigator Garmin GPSMAP 62S.

A total of six transect lines (T1-T6, each $100 \mathrm{~m}$ ) was arrayed out randomly over the study site. Distances between lines were kept $100 \mathrm{~m}$ as far as a minimum measure in order to keep data independent. Line straddling over different micro-habitats was considered for the micro-habitat over which its most part fell. A maximum width of $20 \mathrm{~m}$ on either side of line was set as delimiting belt for each transect(17). Surveys were conducted for a period of seven months, once in each month from November, 2015 to May, 2016. On average 15 minutes was spent on each transect line in the early morning (0730-0930 hrs) to record observations. Even ratio of count sequence among transects was assured with care. Birds were counted based on direct observation as well as by calls. Species flying overhead were recorded only when those were identifiable. For further confirmation, high-resolution photographs were used as well. Three different sets of categories were assigned to the observed birds: passerines and non-passerines, migrants and residents, grassland generalists and grassland specialists. Siddiqui et al. (2008b), Grimmet et al. (2011) and IUCN Bangladesh (2015a) were consulted for nomenclature and dependency categorization of generalists and specialists ${ }^{(6,18-19)}$.

Khan (2015) was followed to estimate the relative abundance as very common (VC) 80-100\%, common (C) 50 - 79\%, fairly common (FC) 20 - 49\% and few (F) $10-19 \%$ which was calculated based on total sighting per survey attempt ${ }^{(20)}$. 


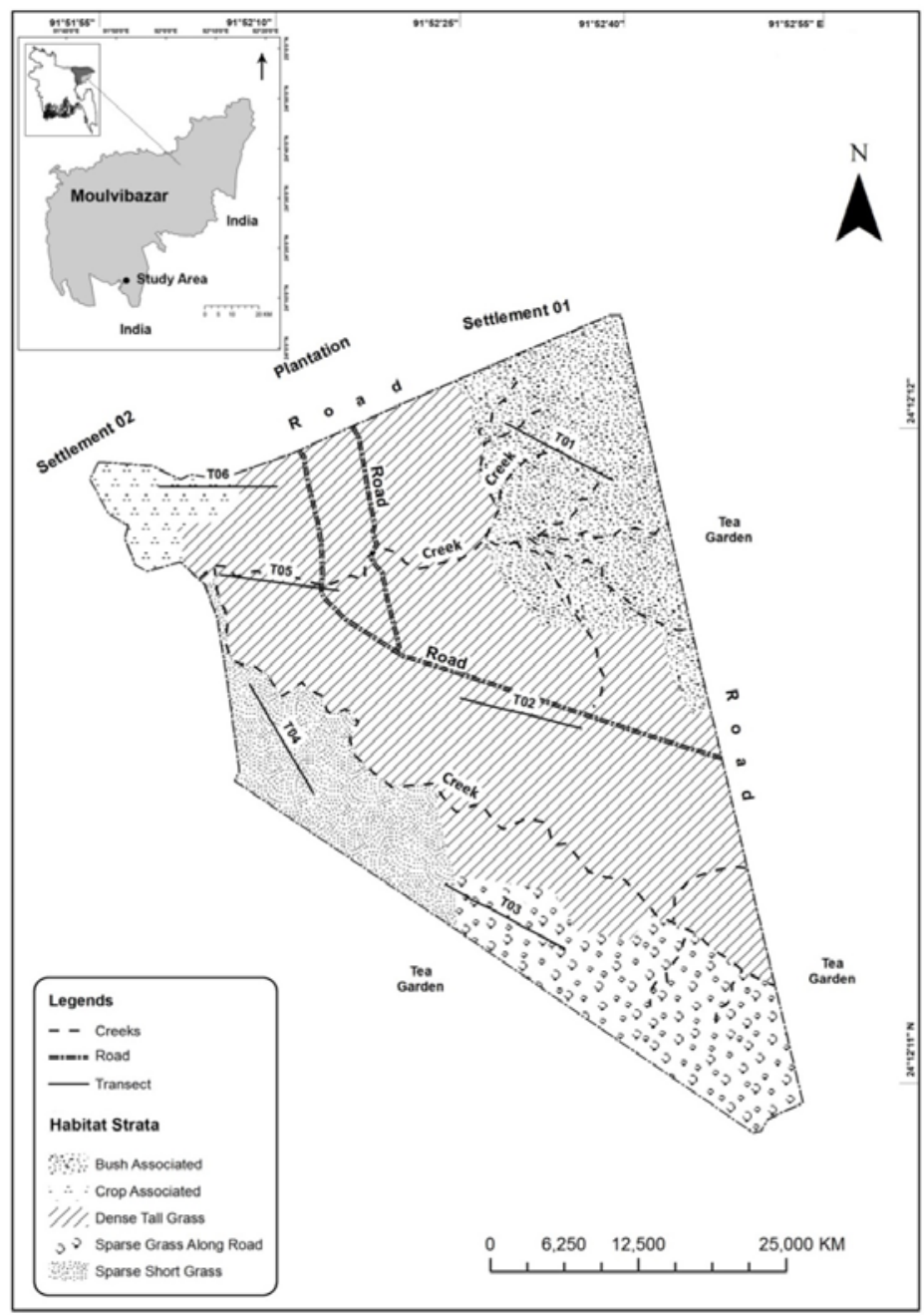

Fig. 1. Map of the study area, micro-habitat stratification and layout of transect lines.

Diversity of avian community against months was probed with Shannon's diversity index $\left(\mathrm{H}^{\prime}\right)$ for total, generalist and specialist species ${ }^{(21)}$. Normality of data was checked using Q-Q plots, Shapiro-Wilk Test and barplots ${ }^{(21)}$. All statistical analyses were carried out with R 3.3.0 utilizing add-in packages i.e., MASS and biodiversityR.

\section{Results and Discussion}

Through seven-month long bird survey, a total of 110 species of birds was skimmed out, of which 39 were categorized as grassland specialists; the rest 71 being generalists (Table 1). Passerine/non-passerine association for generalist species were narrow $($ Generalistn $\mathrm{P}=38$ species, generalistp $=33)$ whereas only seven non-passerine specialist 


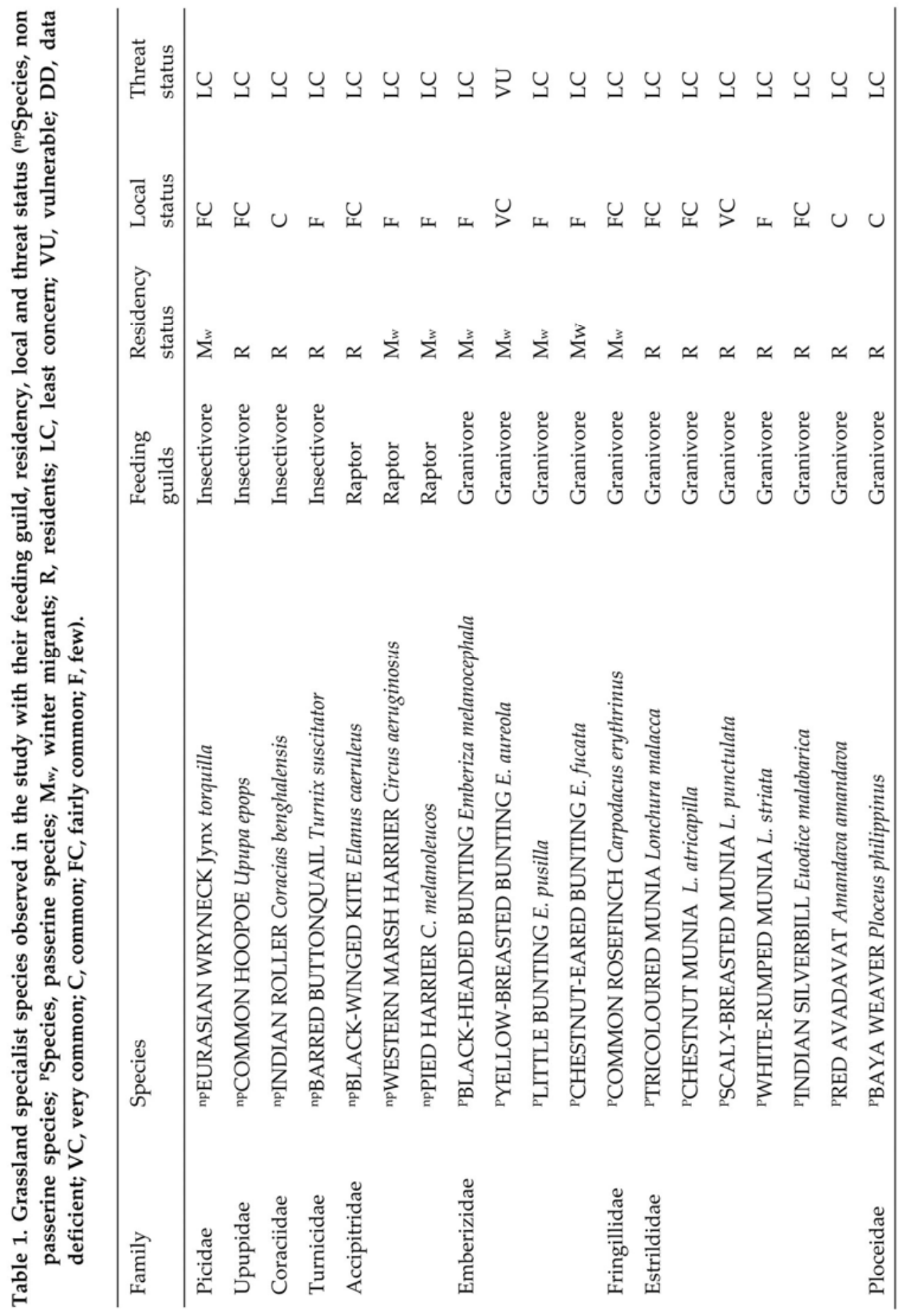




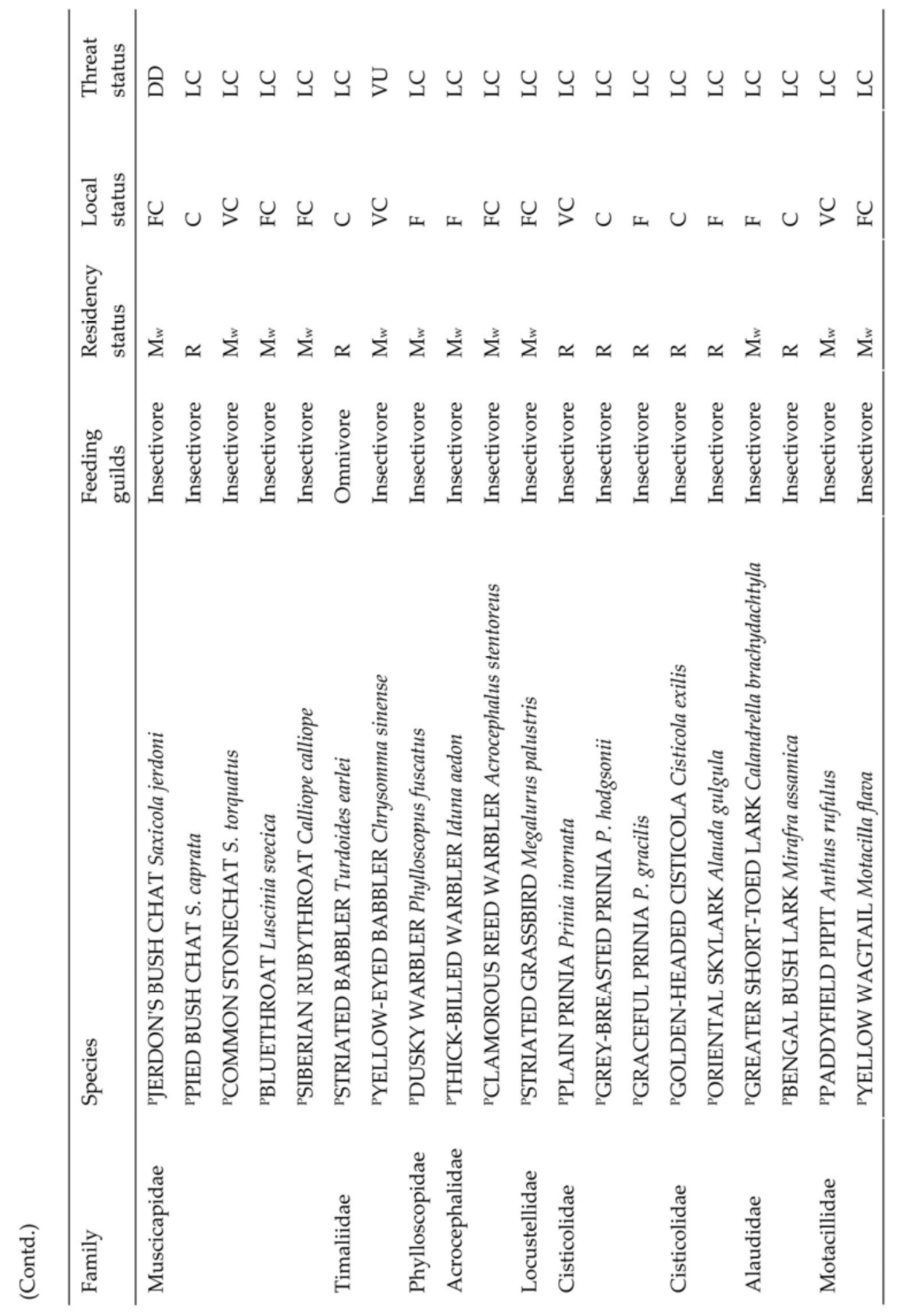


species were observed against 32 passerine specialists. Of the 39 specialist species, 6 $(15 \%)$ were very common, $8(21 \%)$ common, $13(33 \%)$ fairly common and $12(31 \%)$ were few (Table 1).

Change in species richness across micro-habitats over months was found as inflated for December (Table 2). In December, considering microhabitats, dense tall grass $\left(\mathrm{S}_{\mathrm{SDT}}=\right.$ $\left.27, n_{\mathrm{SDT}}=123\right)$, along the creek $\left(\mathrm{S}_{\mathrm{sAC}}=13, \mathrm{n}_{\mathrm{SAC}}=26\right)$ and sparse grass along road $\left(\mathrm{S}_{\mathrm{sSG}}=10\right.$, $\left.\mathrm{n}_{\mathrm{sSG}}=65\right)$ exhibited the most diverse congregation of specialist species. However, the generalists exhibited a spike in index in comparison to a steep decline of specialists onset of March to May which was preceded by slash-and-burn treatment on the habitat (Table 2).

Table 2. Month-wise trend of changes in grassland specialist species $\left(\mathrm{S}_{\mathrm{G}}\right.$, generalist species; $\mathrm{Ss}_{\mathrm{s}}$ specialist species; nG, number of generalist individuals; ns, number of specialist individuals; AC, along the creek; BA, bush associated; DT, dense tall grass; SG, sparse grass along road; SS, sparse short grass; CA, crop associated).

\begin{tabular}{|c|c|c|c|c|c|c|c|c|}
\hline & & November & December & January & February & March & April & May \\
\hline \multirow[t]{4}{*}{$\mathrm{AC}$} & $\mathrm{S}_{\mathrm{G}}$ & 8 & 11 & 15 & 12 & 6 & 4 & 13 \\
\hline & $\mathrm{nG}_{\mathrm{G}}$ & 35 & 29 & 32 & 35 & 20 & 26 & 18 \\
\hline & Ss & 4 & 13 & 4 & 8 & 4 & 0 & 6 \\
\hline & ns & 12 & 26 & 18 & 6 & 6 & 8 & 0 \\
\hline \multirow[t]{4}{*}{ BA } & $\mathrm{S}_{\mathrm{G}}$ & 11 & 23 & 19 & 21 & 11 & 8 & 23 \\
\hline & $\mathrm{nG}_{\mathrm{G}}$ & 83 & 71 & 67 & 53 & 38 & 35 & 25 \\
\hline & Ss & 3 & 7 & 5 & 7 & 4 & 2 & 4 \\
\hline & ns & 11 & 18 & 21 & 11 & 7 & 10 & 7 \\
\hline \multirow[t]{4}{*}{ CA } & $\mathrm{S}_{G}$ & 11 & 27 & 25 & 25 & 19 & 12 & 27 \\
\hline & $\mathrm{nG}_{\mathrm{G}}$ & 91 & 69 & 73 & 80 & 73 & 53 & 46 \\
\hline & Ss & 3 & 9 & 3 & 7 & 2 & 1 & 3 \\
\hline & ns & 7 & 19 & 23 & 9 & 3 & 11 & 2 \\
\hline \multirow[t]{4}{*}{ DT } & $\mathrm{S}_{\mathrm{G}}$ & 4 & 15 & 14 & 12 & 7 & 9 & 16 \\
\hline & $\mathrm{nG}_{\mathrm{G}}$ & 47 & 32 & 29 & 43 & 17 & 16 & 28 \\
\hline & Ss & 4 & 27 & 13 & 10 & 11 & 1 & 15 \\
\hline & $\mathrm{ns}$ & 49 & 123 & 77 & 22 & 27 & 13 & 3 \\
\hline \multirow[t]{4}{*}{ SG } & $\mathrm{S}_{\mathrm{G}}$ & 10 & 16 & 14 & 11 & 7 & 10 & 14 \\
\hline & nG & 39 & 51 & 41 & 31 & 16 & 34 & 26 \\
\hline & Ss & 1 & 10 & 9 & 10 & 2 & 2 & 12 \\
\hline & $\mathrm{ns}$ & 33 & 65 & 37 & 20 & 5 & 1 & 5 \\
\hline \multirow[t]{4}{*}{ SS } & $\mathrm{S}_{\mathrm{G}}$ & 8 & 14 & 13 & 8 & 14 & 9 & 18 \\
\hline & $\mathrm{nG}_{\mathrm{G}}$ & 58 & 35 & 23 & 40 & 44 & 25 & 40 \\
\hline & Ss & 2 & 9 & 9 & 8 & 1 & 1 & 8 \\
\hline & ns & 17 & 37 & 17 & 21 & 2 & 9 & 1 \\
\hline
\end{tabular}

In terms of migratory trend, 33 migrant species were observed (generalistsummer.nP $=1$, generalistsummer. $\mathrm{P}=1$, generalist winter. $\mathrm{P}_{\mathrm{P}}=3$, generalistwinter. $\mathrm{P}=8$, specialist $_{\text {winter. } \mathrm{AP}}=3$, specialist winter.P $=17$ ); with no summer migrant grassland specialists. A total of 19 resident 
grassland specialists were found in the study area (Specialistresident.nP $=4$, Specialistresident. $\mathrm{P}=$ 15) (Table 1).

Birds sighted from the study area were represented by 2586 individuals (nall $=2586$ ). Of total bird densities, specialist species comprised $32 \%\left(n_{s}=829\right) ; 68 \%$ contributed by the generalists $\left(\mathrm{n}_{\mathrm{g}}=1757\right)$.

The largest congregation of avian individuals over the seven-month period was December $\left(\mathrm{nDec}_{\mathrm{C}}=576\right)$ followed by months viz. November $\left(\mathrm{n}_{\mathrm{Nov}}=482\right)>$ January $\left(\mathrm{n}_{\mathrm{Jan}}=466\right)$ $>$ February $\left(\mathrm{n}_{\mathrm{Feb}}=371\right)>\operatorname{March}\left(\mathrm{n}_{\mathrm{Mar}}=359\right)>$ April $\left(\mathrm{n}_{\mathrm{Apr}}=249\right)>$ May $\left(\mathrm{n}_{\mathrm{May}}=196\right)$. Despite this finding, during November, $\mathrm{H}^{\prime}$ index for specialist species was the highest. As aforementioned, though inflation in species richness was observed in December - in particular for the microhabitat of dense tall grass, along the creek and sparse grass along road, specialists yielded the highest value in November $\left(\mathrm{H}_{\text {'sp.nov }}^{\prime}=2.81\right)$ for the study area. Diversity index started lowering as the summer commenced regardless generalists or specialists $\left(\mathrm{H}^{\prime}\right.$ all.apr $\left.=3.22, \mathrm{H}_{\text {all.may }}^{\prime}=2.93\right)$. Comparison of $\mathrm{H}^{\prime}$ indices for total species diversity, generalist and specialist diversity was shown in Fig. 2.

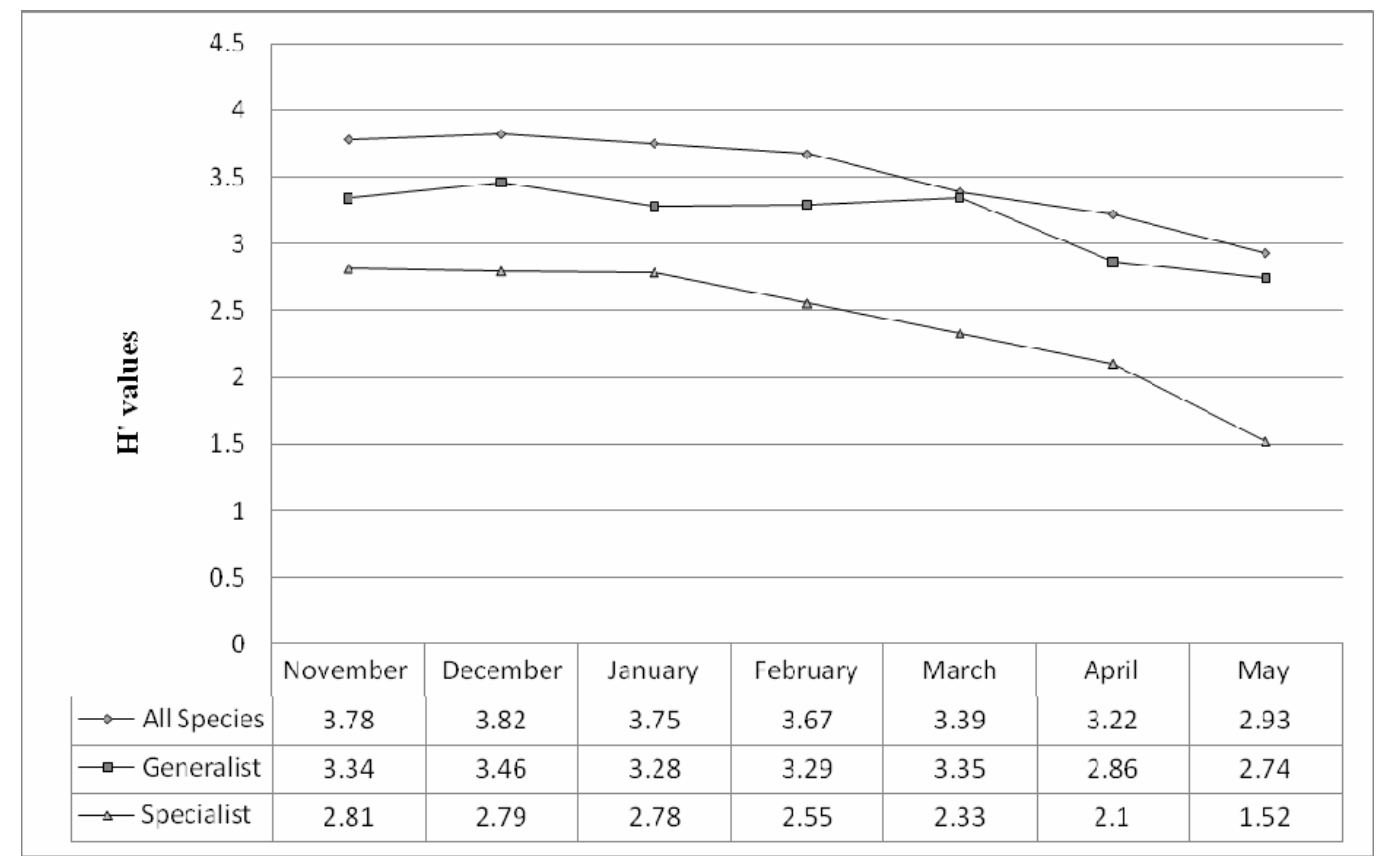

Fig. 2. Shannon's index across months considering all species, generalists and specialists.

Of the generalists, three species of sturnids, two species each from doves and bulbuls appeared to be the most abundant species for all micro-habitats (Fig. 3). In case of specialists, passerines ranked among the most dominated ones in terms of counts of individuals; being led by Scaly-breasted Munia and Yellow-eyed Babbler (Fig. 4). 
Species detected during the study period were categorized into nine feeding guilds. All guilds were sighted from each micro-habitat; however, with sharp changes in abundance over the months (Fig. 5). Birds dependent on insects were the most common and the most profuse across the micro-habitats. Seed-eaters followed after the insectivores. Omnivores and scavengers were respectively positioned third and fourth of the feeding guilds. Guild of nectarivore and molluscivore birds ranked as the lowest of nine categories. Considering the specialists, species from four different feeding guilds were observed i.e., insectivore, granivore, raptor and omnivore whereas the first two being the dominant guilds (Table 1 ).

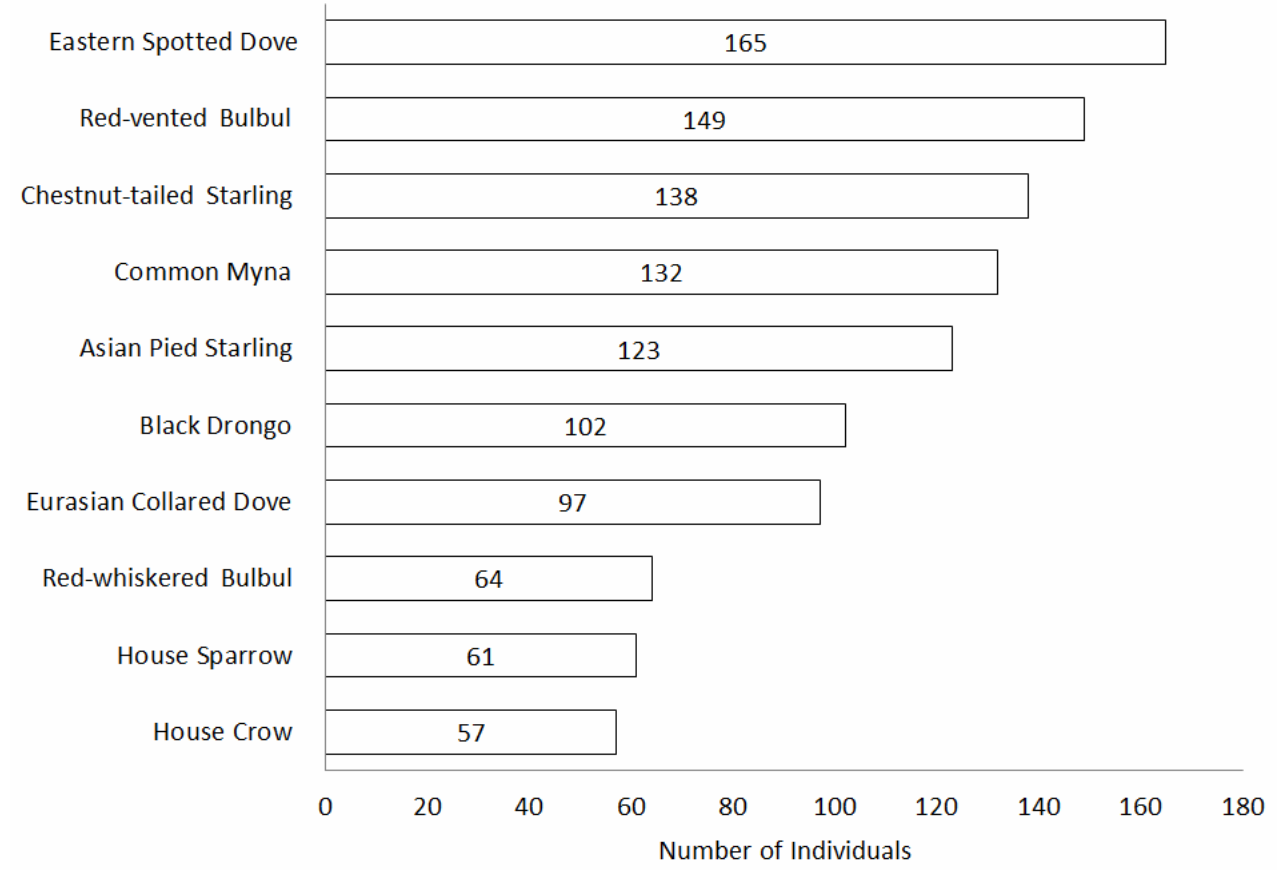

Fig. 3. Grassland generalists (leading ten) in the study area.

The survey presented about $15 \%$ of country's total bird species ${ }^{(20)}$. In general, habitat adapters or generalists were largely dominated (68\%) over the area. Of the generalists, Black-naped Oriole Oriolus chinensis and Indian Cuckoo Cuculus micropterus were the summer migrants. Greater Spotted Eagle (Vulnerable nationally and globally) was the only generalist found as threatened globally and nationally with another species Crested Serpent Eagle Clanga clanga as Data Deficient (DD) for the country ${ }^{(6)}$. It is to be mentioned that Eastern Spotted Dove Spilopelia chinensis was the most abundant generalist species; another two seed-eater - Eurasian Collared Dove Streptopelia decaocto and House Sparrow Passer domesticus also being on the top-ten most abundant generalists' list. 
Likewise, insectivores and seed-eaters, regardless generalists or specialists, were the most dominating in the queue of feeding guilds rather than scavengers and omnivores. Together with these observations, presence of 39 specialists - 32\% in the total composition, up to half in comparison with Khan (1988) - was pertaining to the specialization of the study site's potentiality to harbor habitat specific fauna ${ }^{(12)}$.

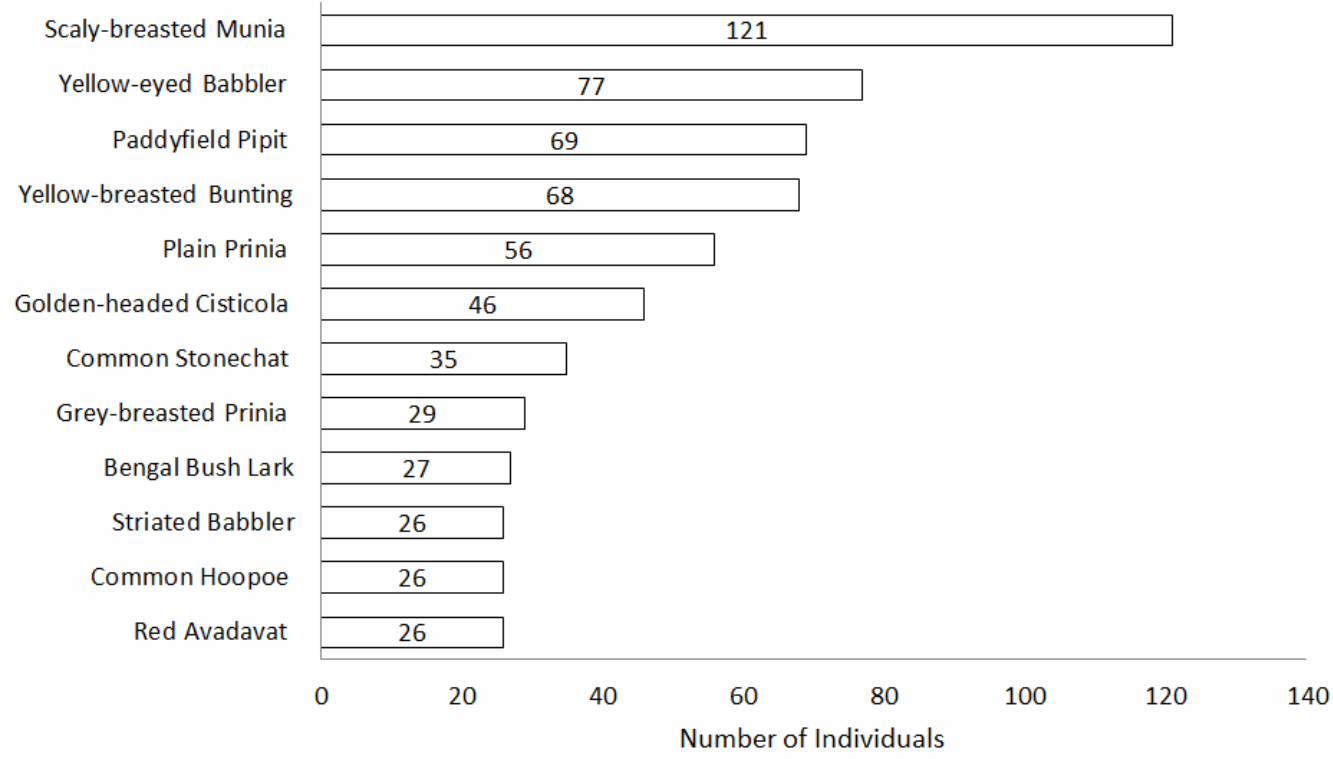

Fig. 4. Grassland specialists (leading ten) in the study area.

Of the resident grassland birds of Bangladesh, all five estrildid finches of Bangladesh were observed; with Scaly-breasted Munia holding the highest density. Other than Scalybreasted Munia, six other resident species were positioned in the most abundant list of specialists (Fig. 5) which encompassed Golden-headed Cisticola and Red Avadavat both. Of fringillid finches, Common Rosefinch, along with, a resident ploceid (Baya Weaver) and four species of rare winter migrant emberizid specialists were sighted i.e., Blackheaded Bunting, Little Bunting, Chestnut-eared Bunting and Yellow-breasted Bunting(6,1819). With the latter as Vulnerable (VU) for Bangladesh and Endangered (EN) globally, another nationally VU species (Yellow-eyed Babbler) was also found. During the peak winter i.e., the surveys from November to January yielded 13 and 68 individuals of Common Rosefinch and Yellow-breasted Bunting correspondingly - being the largest congregation in term of single survey attempt $\mathrm{t}^{(6,10)}$. Black-headed Bunting (two individuals) was observed from transect at dense tall grass on the month of December, it made the finding as fourth country record for Bangladesh ${ }^{(10,22)}$. The study also revealed Golden-headed Cisticola and Jerdon's Bushchat. These grassland diminutives are with scattered information in Bangladesh. The latter is still a Data Deficient whereas the patch 
is so far holding only known breeding population of the cisticola ${ }^{(6,10,23)}$. With presence of diverse and countrywide rare seed-eaters and species relying on long elephant grass, raptors specific to grassland were also found i.e., two species of migratory harriers - Pied Harrier and Western Marsh Harrier and a resident grassland kite of Bangladesh - Blackwinged Kite.

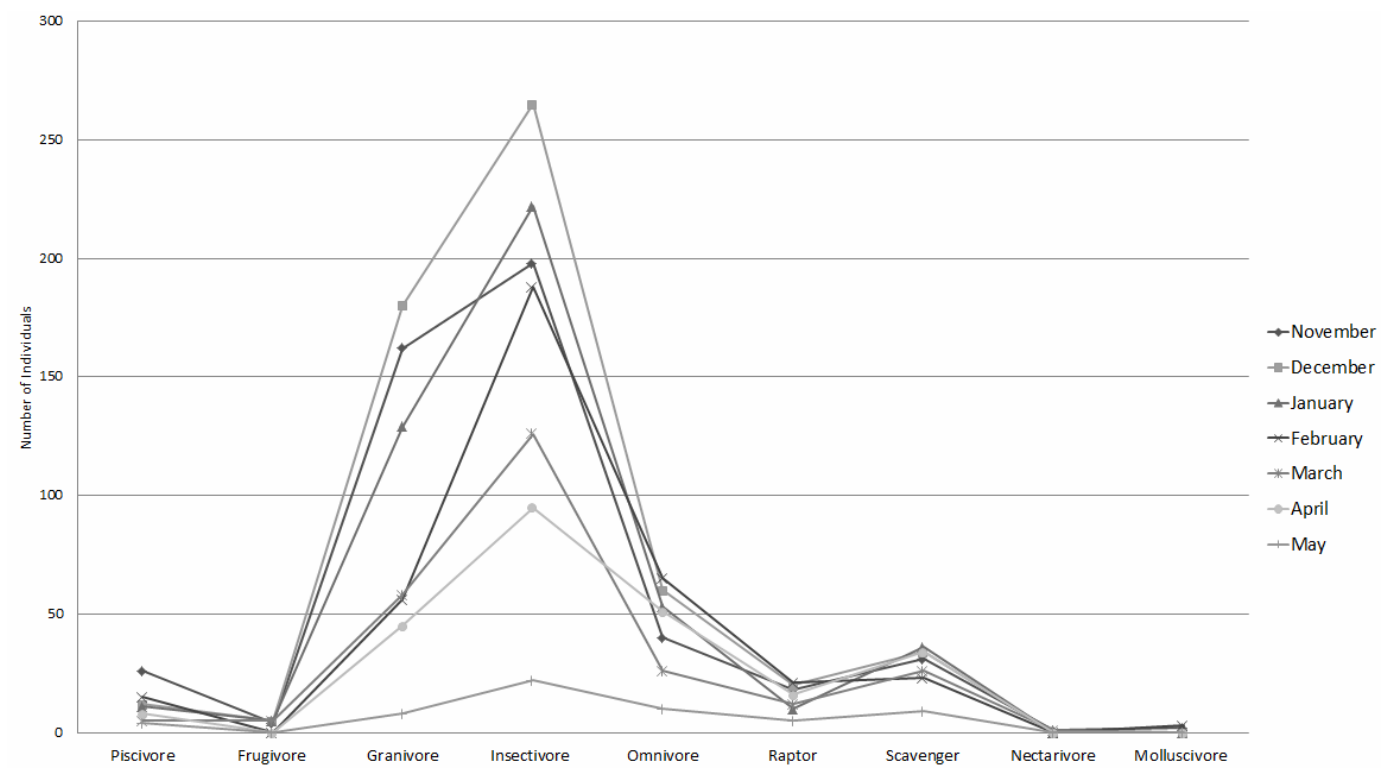

Fig. 5. Different feeding guilds and their variation in abundance over the months.

Native Saccharum contributes largely to the total grasslands (0.8 million hectares) of Bangladesh ${ }^{(6)}$. Moreover, cultivation of sugarcane S. officinarum encompasses about 0.16 million hectares throughout the north and north-west districts ${ }^{(5,24)}$. Ravenna grass is mainly concentrated towards the northeast region having strong presence in almost all of country's 174 tea-gardens, S. spontaneum occupies the central region as well as the vast sand bars on the Ganges and the Jamuna(5,25). Materials for making huts and cottage industries are extracted on yearly basis from the latter two $\mathrm{wo}^{(4,5)}$.

Though enigmatic grassland specialists have gone from Bangladesh, existing grasslands and the Saccharum spreads are still of importance for many species, yielding records in regular intervals ${ }^{(11)}$. Thus, stretches a depiction of exigencies to undertake conservation effort for such habitats; particularly in form of eco-birding for the northeastern tea-gardens.

\section{Acknowledgements}

The authors are thankful to workers and land managers of the Kurma Tea Estate for kindly providing information regarding management practices and for their kind 
permission to work on the site. Gratitude is to the Noazesh Knowledge Centre of the WildTeam for supporting with valuable literary works. The Bangladesh Bird Club created sphere of the project under the Munir Ahmed Khan Bird Conservation Fund.

\section{References}

1. Vickery, PD, JR Herkert, FL Knopf, J Ruth and CE Keller 1995. Grassland birds: An overview of threats and recommended management strategies. In: Strategies for Bird Conservation: The Partners in Flight Planning Process, proceedings of the third Partners in Flight Workshop. USDA Forest Service, US. pp. 74-77.

2. Suttie, JM, SG Reynolds, and C Batello (Eds) 2005. Grasslands of the World (No. 34). FAO, Food \& Agriculture Organization, pp. 471.

3. Garrity, DP, M Soekardi, M van Noordwijk, R De La Cruz, PS Pathak, HPM Gunasena and NM Majid 1997. The Imperata grasslands of tropical Asia: Area, distribution, and typology. Agroforestry Systems 36(1): 3-29.

4. Bor, NL 1960. The grasses of Burma, Ceylon, India and Pakistan (excluding Bambuseae). Pergamon, New York. pp. 767.

5. Ahmed, ZU, MA Hassan, ZNT Begum, M Khondker, SMH Kabir, M Ahmad, ATA Ahmed, AKA Rahman and EU Haque (Eds) 2008a. Encyclopedia of Flora and Fauna of Bangladesh, Vol.12. Angiosperms: Monocotyledons (Orchidaceae-Zingiberaceae). Asiatic Society of Bangladesh, Dhaka. pp. 552.

6. IUCN Bangladesh 2015a. Red List of Bangladesh Vol. 3. Birds. Dhaka: IUCN, International Union for Conservation of Nature, Bangladesh Country Office, Dhaka. pp. 676.

7. Vickery, PD and JR Herkert 1995. Ecology and Conservation of Grassland Birds in Western Hemisphere. Studies in Avian Biology 19: 1-298.

8. IUCN Bangladesh 2015b. Red List of Bangladesh: A Brief on Assessment Result. IUCN, International Union for Conservation of Nature, Bangladesh Country Office, Dhaka. pp. 24.

9. Khan, MS 1977. Flora of Bangladesh. Bangladesh Agricultural Research Council 4: 4-11.

10. Thompson, PM, SU Chowdhury, EU Haque, MMH Khan and R Halder 2014. Notable bird records from Bangladesh from July 2002 to July 2013. Forktail 30: 50-65.

11. Khan, MMH, T Khan, A Ahmed and TA Shovon 2015. Notes on nesting Bristled Grassbird Chaetornis striata, Tanguar Haor, Bangladesh. Birding ASIA 24: 93-95.

12. Khan, MAR 1988. The grassland avifauna of Bangladesh. In: Goriup PD (ed), Ecology and conservation of grassland birds.Technical Publication No. 7. International Council for Bird Preservation, Cambridge.

13. Kottek M, J Grieser, C Beck, B Rudolf and F Rubel 2006. World map of the Köppen-Geiger climate classification. Meteorologische Zeitschrift 15(3): 259-263.

14. Pathak, SD 2005. A statistical profile of Tripura. Population 31(91): 168. available from: http://www.Indianfolklore.org/

15. Ahmed, ZU, ZNT Begum, MA Hassan, M Khondker, SMH Kabir, M Ahmad, ATA Ahmed, AKA Rahman and EU Haque (Eds) 2008b. Encyclopedia of Flora and Fauna of Bangladesh, Vol. 6. Angiosperms: Dicotyledons (Acanthaceae-Asteraceae). Asiatic Society of Bangladesh, Dhaka. pp. 408. 
16. Siddiqui, KU, MA Islam, ZU Ahmed, ZNT Begum, AKA Rahman and EU Haque (Eds) 2008a Encyclopedia of Flora and Fauna of Bangladesh, Vol.11. Angiosperms: Monocotyledons (Agavaceae-Najadaceae). Asiatic Society of Bangladesh, Dhaka, pp. 399.

17. Bibby, CJ, ND Burgess and DA Hill 1992. Bird census techniques. BTO, the British Trust for Ornithology and RSPB, the Royal Society for the Protection of Birds, London. pp. 257.

18. Grimmett, R, C Inskipp, T Inskipp and R Allen 2011. Birds of the Indian Subcontinent. Christopher Helm, London. pp. 528.

19. Siddiqui, KU, MA Islam, SMH Kabir, M Ahmad, ATA Ahmed, AKA Rahman, EU Haque, ZU Ahmed, ZNT Begum, MA Hassan, M Khondker and MM Rahman (Eds) 2008b. Encyclopedia of flora and fauna of Bangladesh. Vol. 26. Birds. Asiatic Society of Bangladesh, Dhaka, pp. 622.

20. Khan, MAR 2015. Wildlife of Bangladesh - Checklist and Guide. Chayabithi, Dhaka. pp. 240.

21. Magurran, AE 2004. Measuring biological diversity. Blackwell Publishing, Oxford. pp.19-215.

22. Chowdhury, SU 2016. Recent Rarities. In:Banglar Pakhi-Bangladesh Bird Club Newsletter. Bangladesh Bird Club, Dhaka. pp. 19-20.

23. Round, PD, EU Haque, N Dymond, AJ Pierce and P Thompson 2014. Ringing and ornithological exploration in north-east Bangladesh wetlands. Forktail 30: 109-121.

24. Rahman, MA, MS Noman, MA Maleque, MZ Alam, S Afroz and MKA Chowdhury 2014. Identification and Distribution of Sugarcane Stem Borer in Bangladesh. SAARC Journal of Agriculture 11(2): 103-116.

25. Ahammed, KM 2012. Investment for Sustainable Development of Bangladesh Tea Industry-An Empirical Study. In: BEA XVIII Biennial Conference Papers, Dhaka. pp. 1-20. 